\title{
Successful Instructional Approaches for Contemporary Students - A Case Study
}

\author{
Heather A. Vilhauer \\ California State University, East Bay \\ Nancy B. White \\ California State University, East Bay \\ Christopher J. Chamberlain \\ California State University, East Bay
}

\begin{abstract}
The purpose of this case study was to learn more about characteristics of contemporary students and to identify teaching methods used to meet the needs of this unique population of students. Semi-structured interviews of tenured, tenure-track and adjunct faculty in the Department of Hospitality, Recreation and Tourism at California State University, East Bay were conducted to obtain their perspectives about challenges faced by contemporary students, teaching methods, and resources. Similarities were found across the academic ranks related to the use of experiential activities, analysis of complex problems with real-world application, use of technology and flexible course policies.
\end{abstract}

Keywords: contemporary students, instructional approaches, teaching methods

\section{INTRODUCTION}

Characteristics of contemporary students in higher education may include delayed entry to college after high school, financial independence, full-time employment, part-time enrollment, having dependents and being a single parent (National Public Radio, 2018; Ross-Gordon, 2011). Contemporary students face significant challenges, not faced by previous generations of students, such as finding a balance between work and family obligations; financial issues; time management; and a lack of skills related to technology, studying and writing (Bell, 2016; Erisman \& Steele, 2012; Regier, 2014; Ross-Gordon, 2011). The purpose of this case study was to learn more about the characteristics of contemporary students and to investigate faculty perspectives of current challenges experienced by contemporary students as well as effective teaching methods for this diverse population.

This study focused on the perspectives of tenured, tenure-track and adjunct faculty in the Department of Hospitality, Recreation and Tourism (HRT) at California State University, East Bay (Cal State East Bay). Perspectives were gathered through semi-structured interviews with department faculty about their teaching approaches, strategies, techniques and methods. Institutional research data were also included. 


\section{Cal State East Bay}

Cal State East Bay is currently recognized as one of the most ethnically diverse campuses in the United States by organizations such as the Chronicle of Higher Education's Almanac, U.S. News and World Reports, and Insight into Diversity Magazine. The University has served the eastern San Francisco Bay Area for more than 60 years (California State University, East Bay [Cal State East Bay], 2019a). In addition to being ethnically diverse, Cal State East Bay is distinctive in terms of average age of the students, the percentage of first-generation students, and the number of students who are working. The average age of full-time undergraduate students is 24 (California State University [CSU] 2019). Firstgeneration students, defined as the first in their family to obtain a college degree, constituted $64 \%$ $(n=8,289)$ of the undergraduate student body in fall 2017 (California State University, East Bay [Cal State East Bay], 2019c). In the 2017-18 academic year, 98\% of full-time undergraduate students were determined to have financial need and received some form of financial aid (Cal State East Bay, 2019a).

In a 2016 survey of Cal State East Bay students, almost 50\% ( $\mathrm{n}=770)$ reported that they had experienced food insecurity, while nearly 1 in 5 respondents reported an episode of homelessness (Taylor et al., 2018). Research has shown that food insecurity and housing challenges can contribute to lower GPAs, health and mental health issues and a decline in attendance/retention (Silva et al., 2015). In a small $(n=51) 2018$ study of Cal State East Bay students, 71 percent noted that work-school conflicts affected their academic progress and over half self-identified as having a mental health condition, learning difference or another type of disability (Taylor et al., 2018).

\section{BACKGROUND}

The changing characteristics of today's students necessitates an investigation of learning styles, teaching strategies and approaches that are effective with contemporary students, to better meet the needs of students, increase student engagement across different groups and increase retention (Wyatt, 2011). Theories and concepts related to teaching and learning that are relevant include andragogy, experiential education, problem-based learning, social development, multiple intelligences, and multicultural competence. Andragogy can be viewed as a theory of adult learning, or more precisely according to Day and Baskett (as cited in Gibbons \& Wentworth, 2001, p. 3) as an educational ideology rooted in inquirybased learning. The focus of this approach is on the learning process. Knowles' theory of andragogy (1992) is based on assumptions about the needs of adult learners, such as the need for experiential learning (based on finding solutions or possible solutions for real-life problems), completion of tasks with immediate value, understanding why information needs to be learned, self-direction and focusing on a task or problem. Service-learning experiences, internships, field experiences and other experiential education activities help transfer learning from the classroom into the community, and help students develop a broader understanding of the real world (Eyler, 2009).

Problem-based learning involves the use of complex real-world problems, designed to help students develop problem-solving abilities and critical thinking/communication skills (Savery, 2006). Vygotsky's social development theory (Daniels, 2008; Vygotsky, 1978) focuses on the fundamental role of social interaction in cognitive development and establishing meaning, the importance of dialogue and collaboration, guided learning that takes place in the zone of proximal development and is influenced by life experiences and scaffolding. The learner is active in this approach, and the teacher is a co-constructor and collaborator. Gardner's theory of multiple intelligences (Armstrong, 2018; Gardner, 1991) relates to cognitive functioning and delineates at least eight different types and combinations of intelligences to interpret human potential broadly. Gardner (as cited in Armstrong, 2018) views intelligence as capacity and makes a distinction between multiple intelligence theory and learning styles. Use of interactive technology is one teaching method that can have value as an educational tool when there is an understanding of multiple intelligences (Veenema \& Gardner, 1996).

According to the National Center for Cultural Competence (as cited in Smith, Johnson, Powell \& Oliver, 2011, p. 3), multicultural competence involves the integration of culturally competent principles into organizational policies and procedures. An institution of higher education can demonstrate that 
diversity is valued through the provision of service-learning programs, inclusive policies and the development/assessment of student learning outcomes at various levels (institutional/department/course). Approaches to building multicultural competence in students include infusing opportunities for selfreflection, cross-cultural interaction, understanding of privilege and increasing awareness of the cultural backgrounds, biases, values, and assumptions of self and others (Smith et al., 2011). The same approaches have been useful for building multicultural competence in faculty.

\section{METHODS}

As the purpose of this study was to investigate faculty perspectives of current challenges experienced by contemporary students as well as effective teaching strategies for this diverse population, a qualitative case study design was chosen. Case study research provides a means for developing a comprehensive, holistic understanding of an issue (Ary, Cheser Jacobs, Sorenson, \& Walker, 2010). A set of semistructured interview questions (Bernard, 2000; Drever, 1995) was developed to obtain faculty perceptions about challenges experienced by contemporary students and effective teaching strategies for this diverse population. After approval from the Cal State East Bay Institutional Review Board, interviews were conducted in person/by phone $(n=12)$ or by email with follow-up emails/phone calls as needed $(n=7)$. Responses were manually submitted to Survey Monkey, a survey platform to organize and analyze the information.

Most of the data collected were qualitative, obtained through the use of open-ended questions about teaching style, student characteristics, challenges, pedagogy, and resources. The researchers worked together to code the data, to identify recurring patterns and themes. A few closed-ended questions, mostly demographic, were also asked as part of the interview. Descriptive statistics were used to analyze quantitative data.

In addition to faculty interviews, institutional data were reviewed and reported using descriptive statistics. This data demonstrated the diversity of the campus and to helped to gain a better understanding of the demographics of students and faculty. Institutional and specific departmental data on faculty and students are publicly available through Pioneer Insights, a dashboard provided to assist with planning and decision-making at the university as well as through the 2018-19 University Facts and Quick Enrollment Facts websites (California State University East Bay [Cal State East Bay] 2019a, 2019c).

Although more recent information was available, data from fall 2017 were used in the study so that comparisons could be made with the available faculty data from the same period (Cal State East Bay, 2019b, 2019c). Indicators studied at the university, and department level for students and faculty include gender and ethnicity. Other student indicators studied include full/part-time status, Pell Grant eligibility, first-generation status and class level.

\section{RESULTS}

Faculty members in the Department of Hospitality, Recreation and Tourism at Cal State East Bay $(\mathrm{N}=21)$ were asked to participate in the study. Faculty included tenured, tenure-track, and lecturers (adjuncts). A total of 19 faculty interviews were completed over two months, for a $91 \%$ response rate. Forty-seven percent $(47 \%)$ of the faculty members responding were female $(n=9)$, and $53 \%$ were male $(n=10)$. Lecturers (adjuncts) constituted $74 \%(n=14)$ of the respondents, and the remaining 26\% were tenure/tenure-track faculty members. Five tenure/tenure-track faculty members did not participate in the study, including the three researchers.

Respondents have taught at the college level for between 3 to 40 years, with the mean being 14 years. Years teaching at Cal State East Bay ranged between 2 and 22 years, for a mean of 8 years. Forty-seven percent $(47 \%)$ of the faculty members have taught at other universities, and $53 \%$ have taught only at $\mathrm{Cal}$ State East Bay. All of the respondents (100\%) teach undergraduate students, many $(95 \%)$ teach general education courses and the majority teach $(84 \%)$ department core courses. Over two-thirds of respondents $(68 \%)$ teach major specialty courses and over one-third (37\%) teach graduate courses. 


\section{University and Department Demographic Data}

Data provided by the Office of Institutional Effectiveness and Research at Cal State East Bay (2019a, 2019b, 2019c) indicates that the campus is highly diverse. Enrollment data for fall 2017 for students at Cal State East Bay is reported. Overall enrollment was 15,435, including undergraduate and graduate students. Undergraduate students represent $84 \%(n=12,998)$ of this total. The majority of undergraduate students on the campus were women $(61.6 \%)$, which has been a consistent trend over time at this institution and other universities in the United States. Of the undergraduate student population, 64\% $(n=8,289)$ were first generation and $52 \%(n=6,722)$ were Pell Grant eligible. The majority of undergraduate students were juniors and seniors $(73 \%, n=9,457)$. Undergraduate students entering their first year of higher education for the first time made up $12 \%(n=1,420)$ of the student population, and $18 \%(n=2,395)$ were first-time transfer students.

A comparison of gender and ethnicity from fall 2017 is shown in Table 1 for university students $(\mathrm{N}=15,435)$ and university faculty $(\mathrm{N}=880)$ as well as HRT students $(\mathrm{N}=294)$ and HRT faculty $(\mathrm{N}=27)$. There were more women than men in all four populations. Over fifty-four percent $(54 \%, n=8,280)$ of the university student population was Hispanic/Latino and Asian, 10\% $(\mathrm{n}=1,507)$ was Black/African American, 20\% $(n=3,240)$ was Multiple Ethnicity, Race/Ethnicity Unknown, Hawaiian/ Pacific Islander, International, and American Indian or Alaska Native, and the remaining 16\% $(n=2408)$ was White $(\mathrm{Cal}$ State East Bay, 2019b, 2019c). Cal State East Bay has been designated as an Hispanic-serving institution, with $25 \%$ or more total undergraduate Hispanic full-time equivalent student enrollment. The methodology for data collection, categories, and definitions of terms were developed by the Office of Institutional Effectiveness and Research.

TABLE 1

GENDER AND ETHICITY

\begin{tabular}{|c|c|c|c|c|c|c|c|c|c|}
\hline \multicolumn{2}{|c|}{$\begin{array}{l}\text { Cal State East Bay } \\
\text { Fall } 2017\end{array}$} & \multicolumn{2}{|c|}{$\begin{array}{c}\text { University } \\
\text { Students }\end{array}$} & \multicolumn{2}{|c|}{ HRT Students } & \multicolumn{2}{|c|}{$\begin{array}{c}\text { University } \\
\text { Faculty }\end{array}$} & \multicolumn{2}{|c|}{ HRT Faculty } \\
\hline & & $\mathrm{n}$ & $\%$ & $\mathrm{n}$ & $\%$ & $\mathrm{n}$ & $\%$ & $\mathrm{n}$ & $\%$ \\
\hline \multirow[t]{3}{*}{ Gender } & Female & 9544 & $61.8 \%$ & 205 & $69.7 \%$ & 494 & $56.1 \%$ & 15 & $56 \%$ \\
\hline & Male & 5891 & $38.2 \%$ & 89 & $30.3 \%$ & 386 & $43.9 \%$ & 12 & $44 \%$ \\
\hline & Total & 15435 & $100.0 \%$ & 294 & $100.0 \%$ & 880 & $100.0 \%$ & 27 & $100 \%$ \\
\hline \multirow[t]{10}{*}{ Ethnicity } & American Indian & 32 & $0.2 \%$ & 0 & $0.0 \%$ & 3 & $0.3 \%$ & 0 & $0 \%$ \\
\hline & Asian & 3475 & $22.5 \%$ & 56 & $19.0 \%$ & 128 & $14.5 \%$ & 3 & $11 \%$ \\
\hline & $\begin{array}{l}\text { Black/African } \\
\text { American }\end{array}$ & 1507 & $9.8 \%$ & 36 & $12.2 \%$ & 64 & $7.3 \%$ & 3 & $11 \%$ \\
\hline & Hawaiian/PI & 126 & $0.8 \%$ & 3 & $4.2 \%$ & 3 & $0.3 \%$ & 0 & $0 \%$ \\
\hline & Hispanic/Latino & 4805 & $31.1 \%$ & 71 & $24.1 \%$ & 63 & $7.2 \%$ & 3 & $11 \%$ \\
\hline & International & 1413 & $9.2 \%$ & 19 & $6.5 \%$ & 17 & $1.9 \%$ & 1 & $4 \%$ \\
\hline & Multiple Races & 852 & $5.5 \%$ & 16 & $5.4 \%$ & 5 & $0.6 \%$ & 0 & $0 \%$ \\
\hline & Unknown & 817 & $5.3 \%$ & 21 & $7.1 \%$ & 89 & $10.1 \%$ & 1 & $4 \%$ \\
\hline & White & 2408 & $15.6 \%$ & 72 & $24.5 \%$ & 508 & $57.7 \%$ & 16 & $59 \%$ \\
\hline & Total & 15435 & $100.0 \%$ & 294 & $100.0 \%$ & 880 & $100.0 \%$ & 27 & $100 \%$ \\
\hline
\end{tabular}

Note: Data obtained from Cal State East Bay (2019b, 2019c).

Although there is a diverse population of faculty at the university and department level, the faculty population is not as representative of underrepresented minorities (URM) as the student population. URM is defined for data analysis purposes by the Office of Effectiveness and Research at Cal State East Bay as 
American Indian, Black/African American, and Hispanic/Latino. The overall population of URM students in fall of 2017 (Cal State East Bay, 2019c) was 41\% ( $n=6,344)$. The URM for university faculty in fall 2017 was 15\% ( $n=130)$, and 22\% (n=6) for HRT department faculty (Cal State East Bay, 2019b).

Undergraduate part-time students are defined at Cal State East Bay as taking fewer than 12 units. Data from Cal State East Bay $(2019 b, 2019 c)$ were used to compare the percentage of part-time undergraduate students enrolled at the university $(\mathrm{N}=12,998)$ and in the department $(\mathrm{N}=265)$. In fall 2017, the university had 13\% $(n=1,692)$ part-time students enrolled and the HRT Department had 16\% $(n=42)$ part-time majors and minors enrolled. There was a slight drop in overall enrollment at the university $(\mathrm{N}=12,316)$ and department $(\mathrm{N}=242)$ in fall 2018 , due in part to a conversion from quarters to semesters that was implemented at that time. The number of part-time enrolled undergraduate students increased in fall 2018, perhaps also in response to the system change, with $19 \%(n=2,296)$ at the university and $27 \%$ $(n=65)$ in the department. Many contemporary students work out of necessity, often taking paid jobs in the industry, they are studying to earn a living and gain practical experience while attending school. Online and hybrid courses in the department are in high demand, in large part due to the needs of students to balancing work, school and family obligations.

\section{Faculty Perspectives of Student Characteristics}

Many of the faculty descriptions about the characteristics of the students taking their courses are in line with university demographic data. Faculty described students as working, busy, culturally and ethnically diverse, first generation, individuals with disabilities, more female than male, and with outside responsibilities for spouse/family/children. Some faculty described their work with older students who are returning after a break from school or transferring from another school. Other faculty work primarily with first-year students in general education courses. Many faculty reported that students are heavily involved with technology and lack social as well as verbal and written communication skills. One faculty member noted that some students underestimate the importance of self-discipline.

\section{Teaching Styles}

The majority of faculty use a combination of teaching styles, incorporating some elements of traditional pedagogical approaches like short lectures that are teacher-directed, along with andragogic approaches based on self-directed learning theory with the instructor as a guide or leader (Gibbons \& Wentworth, 2001). Most respondents reported that their teaching styles have changed since they first began teaching.

Adaptations in teaching styles were made as a result of the changing student population, changes in the field, and in the format the course is delivered in. The Department of Hospitality, Recreation and Tourism offers courses in multiple formats, including face-to-face, hybrid, and online. One faculty member reported:

I changed my teaching style from a traditional lecture model to what the students need, a more interactive, discussion-based model. The focus is now on encouraging students to see beyond the classroom to everything out there (both on campus and in the community).

This idea was reinforced by another faculty member, who felt that a change from the use of traditional testing methods to assess student learning was also necessary as time progressed.

I got the sense that students were memorizing facts but [were] not actually able to apply concepts, so I transitioned to requiring more writing and discussion with classmates to see that they actually knew the material and could apply it to a real-world context.

Faculty also discussed making classes more accessible to all learning styles and being more flexible in content delivery were discussed. Another change in teaching style related by a faculty member was 
trying to tap more into the experiences of students through assignments that involve current and relevant topics. The faculty member stated:

The student population and its nature play a big role with impacting the research and discussion topics I give in my courses. For example, topics that relate to social justice, diversity, safety, technology, and sustainability are not only of interest to our population but are critical to our field and are timely topics.

Faculty who have taught at multiple institutions noted that adaptations in teaching style since starting to teach at Cal State East Bay included providing more flexibility in the course without diluting the quality of the course content. Coming to understand that the students are working, commuting, have responsibilities for childcare for their children or siblings, have other family obligations, have helped faculty evolve to focus on opportunities for students to succeed beyond the classroom.

\section{Instructional Approaches for Contemporary Students}

Faculty identified several different instructional approaches that were successful with contemporary students. These approaches included utilizing experiential activities, having students analyze complex problems with real-world applications, using technology and multimedia in the course, and providing flexibility in course policies and the way that the course is organized. Each of these approaches, with details from interviewees, is provided below.

\section{Utilizing Experiential Activities}

Interviewed faculty members reported that providing opportunities for hands-on learning is a powerful and effective teaching approach when working with contemporary students. Assignments that included an experience, followed by a reflection and application of the concepts learned help students grasp and retain the information. Experiential activities mentioned by many of the faculty included field work, with students going out into the community to interview, observe and interact with others. Job shadowing or interviewing industry professionals was also mentioned as it assists students in learning more about competencies, job duties and challenges of practitioners in a career pathway as well as providing an opportunity to build communication skills. Other types of fieldwork faculty assign included interviews and interactions with individuals of different ages, genders, ethnicities, cultures, and life circumstances to help students learn more about the perspectives of others, and reinforce concepts taught throughout courses involving diversity, social justice, inclusiveness, and wellness.

Faculty also mentioned the use of immersive activities that involve experiences that can help move students out of their comfort zone and gain new perspectives. One faculty member provided an example of an immersive activity is dark dining. During the activity, the students eat a meal in a darkened room where the food and drinks being consumed cannot be seen. This activity is designed to raise awareness about the challenges faced by visually impaired individuals, sharpen the senses and increase enjoyment of the food/drink. Another immersive activity that raises awareness requires students to navigate throughout an area in a wheelchair, on crutches, or blindfolded with or without the assistance of a partner. Other faculty mentioned using online games like Second Life, as they provide an opportunity for students to experience a different gender or ability level as they take on the role of a character in a virtual world. Students self-selection and participation in leisure activities that are not viewed as traditional for their gender is another type of immersive approach used by faculty to investigate gender lines, encourage new experiences, and raise awareness. Service-learning opportunities are used frequently by faculty members to provide an immersive new experience, expose students to the industry, and provide an opportunity for reflection. Faculty noted that encouraging students to go beyond their comfort zone and try something new and then assign value or meaning to the experience was beneficial in terms of overall learning. 


\section{Analysis of Complex Problems with Real-World Application}

Many faculty members felt that the analysis of complex problems with real-world applications is a highly effective approach for teaching contemporary students. One faculty member stated that practical and relevant content that applies to student's lives, situations and experiences is more meaningful to their learning, others noted that they needed to relate to their coursework to see value in it. Because many of the students in the department work in the industry they are studying; it is important to provide opportunities for students to openly express their positions on critical issues and share their practical knowledge. Discussion and analysis of timely and current problems/issues that are relevant to students and the industry is a great strategy to actively engage students, provoke thought, and encourage independent learning. Use of case studies, scenarios, role-playing and project-based learning, result in something a student that can take away and use, that is personal and practical. Inquiry-based, cooperative learning that involves solving problems and making decisions based on evidence builds career and life skills. Using stories to bring information alive was mentioned by one instructor as a useful approach. Other faculty noted that an andragogic approach, that is increasingly self-directed, task or problemcentered and based on real-life enhances the learning for students.

\section{Use of Technology and Multimedia}

Many faculty noted that contemporary students are very connected to technology. Because of this, they make a point of incorporating the use of computers, tablets, pads, watches, and phones into course activities, with structured use of the devices. Throughout the course, students may be encouraged to use phones or other devices as tools to do research, which represents a shift to an investigative approach to locating information and evidence independently rather than a more traditional lecture-based approach with the presentation of evidence. One faculty member stated that activities involving technology and cell phones work well to keep students interested and engaged. Some faculty members make use of videoconferencing to bring in guest speakers or interact with others, integrate videos/movies into course activities, and use online assessments/virtual games/software/application. In the words of one faculty member, "Students do not expect live interaction in an [asynchronous] online course, so a video, conference call, and other interactive techniques are appreciated."

Online resources may be used for students to complete a leadership style assessment, time diary, nutrition tracker, calculate lifespan, or identify resources available where they live that will enable them to maintain wellness throughout their life span. Software used in industry can be used in courses so that students can become familiar with tools used to reserve hotel rooms, schedule recreation programs, or book travel. One faculty member is a firm believer in Gardner's theory of multiple intelligences, which states that students gain understanding, learn, retain information and perform in different ways because they have different minds (Gardner, 1991). "I am intentional in trying to come up with class assignments and activities that appeal to a broad range of student intelligences including visual-spatial, bodilykinesthetic, logical-mathematical, etc." Faculty noted that the use of multimedia, educational technology, and online tools could facilitate learning and are effective teaching approaches for contemporary students.

\section{Flexible Course Policies and Organization}

Given the many demands on contemporary students, many faculty members feel it is essential to provide flexibility in course policies, alternative assignments, multiple chances to take quizzes, deadline options, or assignment modification when necessary. One faculty member stated, "Students are juggling a lot in life, need deadlines and clear expectations to stay on track, along with some flexibility to deal with life situations." Because contemporary students often work, commute and have challenges, some faculty members use a more lenient approach. According to a faculty member, "I had to adapt my teaching and design deadlines to take into consideration the fact that a good majority of my students are working adults."

Students' lives have become more hectic, and the likelihood of success is improved if they have a clear path and unnecessary barriers are removed. One teaching style adaptation a faculty member made was moving from designing classes to catch the cheater (punitive, with deductions made for late work) to 
making exceptions and getting creative when students do not have access to necessary resources. The faculty member discovered that most students are hard-working, juggling work and life, and as such wanted to find a way to respect and honor their efforts in the course.

There were some differing perceptions among faculty members about how to best organize courses to meet the needs of contemporary students. One faculty member addresses the needs of students who "have a lot more stress and anxiety than they used to" by introducing upcoming work no more than one to two weeks in advance, so students do not feel overwhelmed and can stay on task. Other faculty members mentioned the importance of structure in the course and preferred a more linear approach with clear deadlines and timelines. One faculty member emphasized the need for, "a similar submission process, clear expectations, and access to the full course from day one so they can pace themselves based on their schedule and other commitments." Many also noted the importance of providing more support and being available to meet with students in person or virtually, and not necessarily just during set office hours, especially with students who are busy, distracted and may not be self-motivated. Several faculty members mentioned providing their students their cell phone numbers and encouraging them to call and text when needed.

\section{Faculty Background and Experiences}

Faculty were asked about how their race/age/culture/socio-economic status impacted their teaching. In responding to this question, faculty responded in a few different ways. Many of our faculty, which more closely reflect students in terms of their demographics and background use that to build relationships within the classroom. Faculty noted that sharing their personal experiences in college and in industry, helped to build relationships with students, who often do not have people who can relate directly to their situations. Faculty who do not reflect students in the same ways noted that they had to be aware of the privilege that they have had and be respectful of the way that it might be perceived in the classroom.

The majority of faculty noted that no matter their background or experience, it was essential to build a relationship with each student. Faculty noted that students wanted to felt heard and understood, both in the course and on campus. Many faculty provided numerous ways for students to reach out to them and encouraged them to contact them when needed (Zoom, telephone, email, and in-person).

\section{Addressing Challenges of Contemporary Students}

Faculty members were asked about the most significant challenge they felt contemporary students face. "Multiple responsibilities and challenges, pressures from everywhere. The juggling of schedules and expectations. Many are first-generation students who don't have anyone to ask questions of, they don't have the resources that others do," was the response of one faculty member. Other student challenges discussed by the faculty members were time (work and family obligations), money (food insecurity, homelessness, transportation challenges, can't afford to purchase required textbooks or computers), emotional and mental stress, lack of work/school/life balance and lack of skills (critical thinking, time management, written and verbal communication). Major societal issues, social pressures and a feeling of disconnect between students and the university were also mentioned.

Most faculty members were aware of on- and off-campus and resources available to help contemporary students with the challenges they face, and often refer students to those resources. In terms of academic assistance, faculty noted that they often refer students to the Writing Center and Student Center for Academic Achievement to help students develop stronger writing skills and obtain tutoring. Faculty also referred students to the Academic Advising and Career Center which provides academic counseling and specialized assistance to help assure academic success. Many faculty encourage students to take advantage of library resources as well. For students on campus, the library is an excellent resource for students who need assistance with locating academic resources, finding a quiet place to study, or providing a place to meet with a study group. For students who are not on-campus regularly, the library provides a wealth of online resources designed to assist online students. The Center for Community Engagement, Accessibility Services, Financial Aid, Instructional Technology and the Department of 
Hospitality, Recreation and Tourism were other campus resources that students are referred to for academic assistance.

Students are often referred to the Office of Financial Aid for assistance in the form of grants, scholarships, and student loans. Cal State East Bay provides housing and food assistance for students through the Helping Our Pioneers Excel (HOPE) program. Other referrals made to students are to the Food Pantry, Student Health and Counseling Services, Confidential Campus Advocate (crisis counseling and recovery), Mental Health Programs, Student Housing, and Veteran's Affairs. Faculty members also refer students to the Recreation and Wellness Center (RAW).

\section{Preparation to Teach at a Highly Diverse University}

The majority of faculty members in the Department of Hospitality, Recreation and Tourism, felt prepared to work with contemporary students when they were hired at Cal State East Bay. Many discussed their prior work experiences in industry, teaching experience at other institutions of higher education (some with similar demographics) and personal background/experiences as preparation for teaching at a highly diverse university. Although many felt prepared, others noted that having background information about the student demographics at this institution, and knowledge of the resources available to students would have provided better preparation. Faculty also noted that they would like more information about working with both the Faculty Development and Instructional Technology departments on campus.

Tenure and tenure-track faculty attend a new faculty orientation at the start of their first year, which is very helpful in preparing faculty to teach at Cal State East Bay. However, some lecturers (adjuncts) mentioned that an orientation would be useful to improve their knowledge of the school and acclimate to this unique environment, as they are currently given very little information beyond human resources materials. Suggestions were also made that a more formal mentoring process, perhaps being assigned a department faculty mentor, would be useful in addition to the guidance provided by the department chair.

\section{DISCUSSION}

The results of this case study provide information that is useful for faculty members working with contemporary students, to help them gain understanding about student challenges, effective instructional approaches, and utilization of resources for this distinctive population. A limitation of this preliminary study was the use of a small convenience sample of faculty members from one department, at one university. Although results are not generalizable, there is value in learning about the perceptions of faculty members who teach at a diverse university and have first-hand knowledge about approaches that work well with contemporary students. Faculty members from the Department of Hospitality Recreation and Tourism at Cal State East Bay who were interviewed reported the use of a combination of teaching styles that include limited lecturing, relatively little use of traditional testing methods and more focus on self-directed activities to enhance student engagement.

The themes identified with relation to instructional methods that work well with contemporary students were incorporating experiential activities, analysis of complex problems with real-world application, using technology/multi-media and providing some flexibility in course policies/organization. These themes relate to a number of different learning theories and teaching approaches that involve the use of self-directed, collaborative, experiential and problem/task focused learning activities to make content more meaningful for today's students and promote active learning (Gibbons \& Wentworth, 2001; Knowles, 1992; Savery, 2006).

Faculty members who have knowledge of the challenges faced by their students and use a variety of teaching strategies to meet the needs of different types of students are better able to facilitate student

success. Students who understand the importance of what is being studied and see the applicability of the course activities to their lives and the real world are more likely to be motivated and actively involved in their learning (Bell, 2016). Adapting teaching approaches is necessary over time to accommodate changing student demographics, industry advancements and the mode of delivery (face-to-face, hybrid 
and online). Continuous learning, growth, and skill-building are necessary for faculty members as well as students. Content delivery is essential, but the process of learning and helping students develop life skills such as critical/creative thinking, problem-solving, effective communication and interpersonal skills need to be considered as well. Helping students build strong, transferable skills (Eyler, 2009) while imparting subject knowledge is challenging and requires the commitment of students and faculty members.

\section{IMPLICATIONS AND RECOMMENDATIONS}

Understanding contemporary students, as well as effective instructional approaches, is critical to the success of university programs. This case study identified some of the characteristics of contemporary students, identified effective instructional approaches and discussed the importance of understanding how to address the challenges of contemporary students.

This research provides several opportunities for university faculty and staff to take action. Providing support, resources, and assistance to contemporary students outside the classroom as well as inside is vital for their health and academic success. Faculty members (tenure-track, tenured and lecturers) should be aware of resources available to students and share information with them about where to get support in terms of housing, food, financial aid, employment, transportation, health care, counseling, sexual harassment, tutoring, writing assistance, accommodations, accessibility and more. Faculty members can provide general information about resources and support available to students through the syllabi, announcements, and discussions; and in interactions with individual students as appropriate.

New-hire orientations and ongoing educational workshops for faculty members at every level (tenuretrack, tenured and adjunct) should include discussion of topics like diversity, inclusion, campus demographics, challenges, effective teaching methods and resources for contemporary students. Formal and informal mentorship of new faculty members is useful to make new faculty members aware of the needs of contemporary students and to provide them with some tools and ideas about how to meet those needs. Faculty discussions about grading policies, sample assignments, course structure, expectations and flexible approaches to teaching at the department level provide opportunities for faculty members to change, grow and adapt. Universities should continue to actively seek diverse faculty, that is representative of the proportions of the student population. Further research is needed to learn more about the changing characteristics of students and innovative teaching approaches. A holistic approach to teaching that involves taking the needs of the whole person into consideration is important for the success of contemporary students.

\section{ACKNOWLEDGMENTS}

The authors wish to thank faculty members in the Department of Hospitality, Recreation and Tourism at Cal State East Bay for sharing their experiences and expertise. 


\section{REFERENCES}

Armstrong, T. (2018). Multiple intelligences in the classroom (4th ed.). Alexandria, VA: Association for Supervision and Curriculum.

Ary, D., Cheser Jacobs, L., Sorenson, C., \& Walker, D. A. (2010). Introduction to research in education (9th ed.). Belmont, CA: Wadsworth, Cengage Learning.

Bell, A. (2016). Students as co-inquirers in Australian higher education: Opportunities and challenges. Teaching \& Learning Inquiry: International Society for the Scholarship of Teaching and Learning Journal, 4(2), 95-102. Retrieved from http://dx.doi.org/10.20343/teachlearninqu.4.2.8

Bernard, R. (2000). Social research methods: Qualitative and quantitative approaches. Thousand Oaks, CA: Sage Publications.

California State University, East Bay. (2019a). Office of Institutional Effectiveness and Research: 201819 University facts brochure. Retrieved from https://www.csueastbay.edu/about/files/docs/20182019factsbrochure.pdf

California State University, East Bay. (2019b). Office of Institutional Effectiveness and Research: Pioneer insights. Retrieved from https://data.csueastbay.edu/\#/enrollment/majors/overall

California State University, East Bay. (2019c). Office of Institutional Effectiveness and Research: Quick enrollment facts. Retrieved from http://www.csueastbay.edu/ir/index. html

California State University. (2019). CSU East Bay: Student life. Retrieved from https://www2.calstate.edu/attend/campuses/east-bay/Pages/student-life.aspx

Daniels, H. (2008). Vygotsky and research. New York: Routledge.

Drever, E. (1995). Using semi-structured interviews in small-scale research: A teacher's guide. Edinburgh, Scotland: Scottish Council for Research in Education.

Erisman, W., \& Steele, P. (2012). From contact to completion: Supporting returning adult students in obtaining a college credential. Higher Ed Insight. Retrieved from https://higheredinsight.files.wordpress.com/2015/06/adult_college_completion_20151.pdf

Eyler, J. (2009). The power of experiential education. Liberal Education, 95(4), 24-31. Retrieved from https://www.aacu.org/publications-research/periodicals/power-experiential-education

Gardner, H. (1991). The unschooled mind: How children think and how schools should teach. New York: Basic Books.

Gibbons, S. R., \& Wentworth, S. D. (2001). Andrological and pedagogical training differences for online instructors. Online journal of distance learning. Retrieved from http://www.westga.edu/ distance/ojdla/fall43/gibbons_wentworth43.html.

Knowles, M. (1992). Applying principles of adult learning in conference presentations. Adult Learning, 4(1), 11-14.

National Public Radio. (2018, September 4). Today's college students aren't who you think they are. Retrieved from https://www.npr.org/sections/ed/2018/09/04/ 638561407/todays-college-studentsarent-who-you-think-they-are?fbclid= IwAR03svXRQX464Ii2rGf0 EPLSLFJSJ_Sn5iCUjKLYaOPqzibtePXKj5k8r0I

Regier, P. (2014, September/October). Using technology to engage the nontraditional student. Educause Review, 49(5), 70. Retrieved from https://er.educause.edu/ /media/files/articledownloads/erm1454.pdf

Ross-Gordon, J. M. (2011, Winter). Research on adult learners: Supporting the needs of a student population that is no longer nontraditional. Peer Review, 13(1), 26-29. Retrieved from https://www.aacu.org/publications-research/periodicals/research-adult-learners-supporting-needsstudent-population-no

Savery, J. R. (2006). Overview of problem-based learning: Definitions and distinctions. Interdisciplinary Journal of Problem-Based Learning, 1(1). Retrieved from https://docs.lib.purdue.edu/cgi/viewcontent.cgi?article=1002\&context=ijpbl

Silva, M. R., Kleinert, W. L., Sheppard, A. V., Cantrell, K. A., Freeman-Coppadge, D. J., Tsoy, E., . . \& Pearrow, M. (2015). The relationship between food security, housing stability, and school 
performance among college students in an urban university. Journal of College Student Retention: Research, Theory and Practice, pp. 1-16.

Smith, A. B., Johnson, C. W., Powell, G. M., \& Oliver, J. P. (2011). The relationship between multicultural service-learning and self-reported multicultural competencies in undergraduate students: A qualitative participatory action study. SCHOLE: A Journal of Leisure Studies and Recreation Education, 26(2), 1-13.

Taylor, S., Jones-Bey, A. Gamba R., Khosla, N., Engelman, A., Bovey, J., . . \& Inch, E. (2018, August 15). I'm barely just hanging in: Who our students are and how to support them. Presented at California State University East Bay Back to the Bay, Hayward, CA.

Veenema. S., \& Gardner H. (1996, November/December). Multimedia and multiple intelligences. The American Prospect. Retrieved from https://prospect.org/article/multimedia-and-multipleintelligences

Vygotsky, L. S. (1978). Mind in society: The development of higher psychological processes. Cambridge, MA: Harvard University Press.

Wyatt, L. G. (2011, February). Nontraditional student engagement: Increasing adult student success and retention. The Journal of Continuing Higher Education, 59(1), 10-20. 